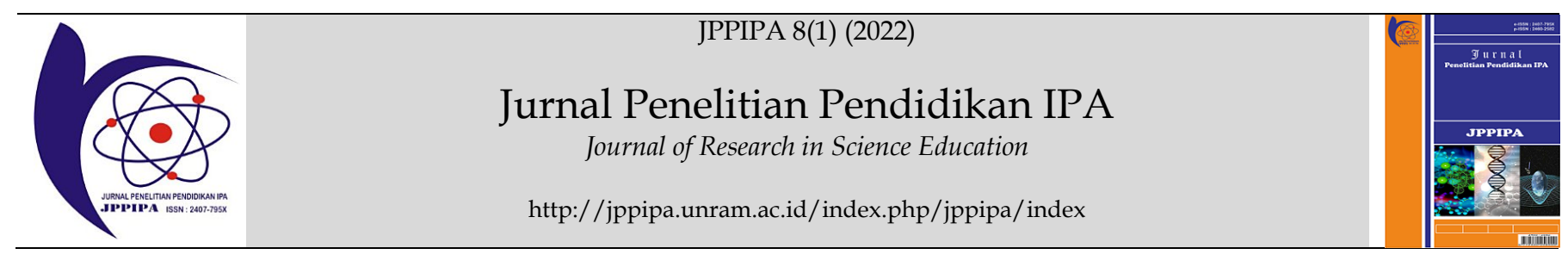

\title{
Development of Android-Based Mobile Learning (M-Learning) on Voltaic Cell Sub Materials to Increase Learning Effectiveness in Pandemic Covid-19 Era
}

\author{
Dei Gratia Kanthi Nabella1 ${ }^{1}$ Kusumawati Dwiningsih ${ }^{1 *}$
}

${ }^{1}$ Master of Chemistry Education Study Program, Faculty of Mathematics and Natural Science, State University of Surabaya, Surabaya, Indonesia

DOI: $10.29303 /$ jppipa.v8i1.1243

\section{Article Info}

Received: December 16, 2021

Revised: January 10, 2022

Accepted: January 12, 2022

Published: January 31, 2022

\begin{abstract}
This study was conducted to know the worthiness of learning media mobile learning (M-Learning) is increasing students' learning effectiveness. Research and Development (R\&D) has adapted the method used. The research was conducted involving 26 students and three validators. The validator consists of 1 lecturer as a media expert lecturer, one material expert, and one chemistry teacher. Based on the study results, the results obtained media validity of $93 \%$, and the effectiveness of the media in terms of increasing student scores as much as $41.9 \%$. So that the android-based M-Learning product developed can be said to be feasible and can be implemented in chemistry learning on voltaic cell sub materials.
\end{abstract}

Keywords: Android-Based Learning; Learning effectiveness; Voltaic Cell

Citation: Nabella, D. G. K., \& Dwiningsih, K. (2022). The Development of Android-Based Mobile Learning (M-Learning) on Voltaic Cell Sub Materials to Increase Learning Effectiveness in Pandemic Covid-19 Era. Jurnal Penelitian Pendidikan IPA, 8(1), 183-187. https://doi.org/10.29303/jppipa.v8i1.1243

\section{Introduction}

The COVID-19 pandemic that hit the world in 2020 had a significant impact, especially on teaching and learning activities carried out in Indonesia (Putria, et al., 2020). Each educational institution must make adjustments and analyze learning conditions to remain effective. Therefore, a lot of learning done initially offline is now starting to be done online. The role of the teacher here is needed to design learning so that it remains effective even with existing limitations. Teachers must carry out several stages, starting from planning, implementing, and evaluating each teaching that is carried out online (Dewi \& Sadjiarto, 2021).

The stages are reinforced by Circular Letter No. 4 of 2020 concerning the Implementation of "Pelaksanaan Kebijakan Pendidikan Dalam Masa Darurat Penyebaran Virus" released by the Minister of Education and Culture (Circular Letter of the Minister of Education and Culture No. 4, 2020). With the letter, learning is carried out from each student and teacher's home so that social distancing can still be applied according to government recommendations.
The teaching and learning process carried out from home does not only involve students and teachers. Creating practical learning activities for students also requires the support and active role of several parties such as family, community, and government (Dewi \& Sadjiarto, 2021).

As a result of online learning, some students now tend to decrease learning motivation (Cahyani et al., 2020). Not only that, students who should be able to carry out learning activities independently actually have a low level of independence (Hidayat et al., 2020). Students who are used to doing learning activities face to face directly, which is now no longer possible to make online learning activities cannot be fully implemented independently. Many factors can be developed to support the realization of a quality learning process, one of which is utilizing technology (Putri, et al., 2021).

Learning innovations carried out by each educational institution should open a new paradigm involving information technology developed recently (Ramdani, et al., 2020). Technology can facilitate access to learning for students so that the harmful impact of 
the pandemic that has been felt lately can be minimized as early as possible. One of the breakthroughs that can be done is to develop android-based learning media (Putri, et al., 2021).

Besides being used as a service provider for communication, Android can be developed as an interactive learning media supporting students (Kartini \& Putra, 2020). Android-based learning media is an alternative solution that can be used in teaching and learning activities. Learning media designed for Android have unique characters and relatively easy accessibility (Oktarina \& Sahono, 2020). The operating system Android is based on a modified version of Linux. Android was developed by Android company Inc which is widely used on mobile platforms (Lubis, I, R., \& Ikhsan, 2021). On the platform provided by Android, development can be carried out by the needs and goals set by the developer.

Mobile learning (M-Learning) is included in the software developed on the android platform to help to facilitate teaching and learning activities during the Covid-19 pandemic. M-Learning is designed as software and interactive learning media to respond to each learning process. In addition, the developed learning media is designed with a size that is not too large, compact, easily accessible and does not require an internet connection. The specifications are essential, considering that not all regions in Indonesia are facilitated by a stable internet connection. In addition, M-Learning is designed to be compact with a small file size so that lower specifications of Android devices can still access it.

The voltaic cell material is used in the development of M-Learning so that students can repeat the definitions of the terms in it. So that students' habits in memorizing the material in understanding concepts can be minimized in their use (Setiawan, et al., 2020). Students often do practical work with various chemicals as electrodes in the voltaic cell sub material. However, along with the pandemic situation, it has not been possible to do learning in the laboratory. With MLearning, students can do practicals virtually anytime and without operational costs (Hadi, 2019).

Similar research has also been carried out, showing that an appropriate Android system learning media is able to improve student learning outcomes (Syarifuddin \& Dwiningsih, 2020). Other studies also state that android-based learning media are suitable for visualizing microscopic subjects during a pandemic (Sophia, 2019; Siahaan, et al., 2020)

Based on the descriptions that have been put forward, the researchers conducted a study entitled "Development of Android-Based Mobile Learning (MLearning) in Voltaic Cell Submaterials to Improve Learning Effectiveness in Pandemic Covid-19 Era."

\section{Method}

The research was conducted in December 2020 at SMAN 1 Ngimbang, Lamongan. The research method to develop interactive learning media Mobile Learning (M-Learning) on voltaic cells is a $4 \mathrm{D}$ (development model four D). This research belongs to the research Research and Development (R\&D), where a product in learning media is developed, and its effectiveness is measured. The stages of the research carried out can be seen in Figure 1.

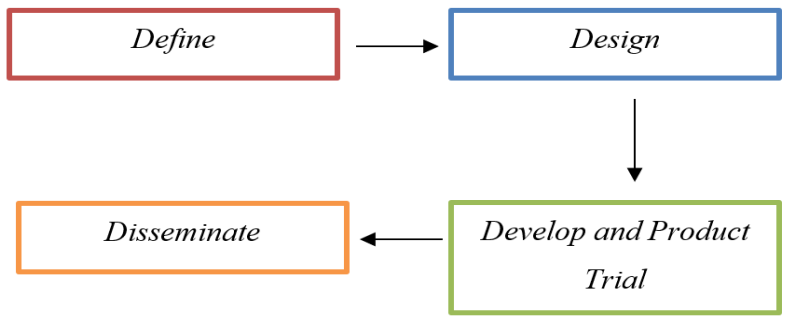

Figure 1. 4D Research Model (Syarifuddin \& Dwiningsih, 2020).

The research was carried out by adapting the $4 \mathrm{D}$ development model start with defining until the development stage and limited trials. The research subjects were two lecturers as media experts and material experts from the State University of Surabaya, one chemistry teacher, and students of class XII MIPA 4 SMAN 1 Ngimbang totaling 26 students.

The research instruments used were questionnaires and Pre-Test and Post-Test sheets for students. Product validation was obtained from a media expert and material expert from the State University of Surabaya. Validation was also obtained from a chemistry teacher from SMAN 1 Ngimbang. To determine the level of product effectiveness, instruments in the form of student responses were used as well as pre-test and post-test sheets.

Data analysis was carried out with the formula:

$$
\mathrm{P}(\%)=\frac{\text { total score of the result }}{\text { criteria score }} \times 100 .
$$

The criterion score was obtained from the highest item score $x$ Number of items $x$ Number of Validators. Scores ranged from very good (5), good (4), moderate (3), poor (2), and very poor (1). Validation percentages are categorized according to the Likert scale in table 1.

Table 1. Product Validity Category

\begin{tabular}{ll}
\hline Percentage (\%) & Category \\
\hline $0-20$ & Very Invalid \\
$21-40$ & Less Valid \\
$41-60$ & Sufficiently Valid \\
$60-80$ & Valid \\
$81-100$ & Very Valid \\
\hline
\end{tabular}

(Syarifuddin \& Dwiningsih, 2020) 
Interactive learning media mobile learning (MLearning) is said to be valid if it meets the percentage criteria $>60 \%$ or in the valid and very valid category (Syarifuddin \& Dwiningsih, 2020). The effectiveness of student learning outcomes is measured based on the average pre-test and post-test scores

\section{Result and Discussion}

Research conducted by adapting the $4 \mathrm{D}$ development model was sufficient for developing limited-stage trials in the third stage. The following is a detailed description of the steps of the research carried out.

\section{Stage Define.}

At this stage, the requirements for the learning media to be produced are determined and defined. Several aspects, such as curriculum, concepts, and students, are analyzed in this stage.

\section{Curriculum analysis}

The product is adapted to the curriculum used at SMAN 1 Ngimbang, Lamongan. According to the Decree of the Minister of Education and Culture of the Republic of Indonesia, the curriculum used is the Curriculum for Education Units in Special Conditions, published on August 4, 2020. In the selection of KD, researchers used KD 3.4. Analyzing the processes that occur in voltaic cells and explaining their uses.

\section{Concept analysis}

At this stage, adjustments are made to the concepts presented in the products and literature used by students. This adjustment is intended so that there is continuity between the textbooks used by students and the media that will be presented. The book used was published by Erlangga with the title Kimia by Michael Purba. Adapting from various sources determines the limitations of the material and menus presented in interactive learning media.

\section{Student Analysis}

There are 26 students from class XII MIPA 4 SMAN 1 Ngimbang, Lamongan. The product is designed as attractive as possible with various images, illustrations and combined with colorful background colors. Thi design is intended to attract students' interest in learning.

\section{Stage Design}

The stage is made to realize the concepts that have been analyzed in the first phase. In designing the product, there are two steps, namely:

\section{Preparation of product components}

The product consists of several menus, namely competence, materials, illustrations, and quizzes. Some information about the product is also presented in the instruction's menu, dafpus, and developer. To realize these menus, icons in buttons and supporting images are also made. Pictures and illustrations adapted from textbooks and the internet with Corel Draw X9 software.

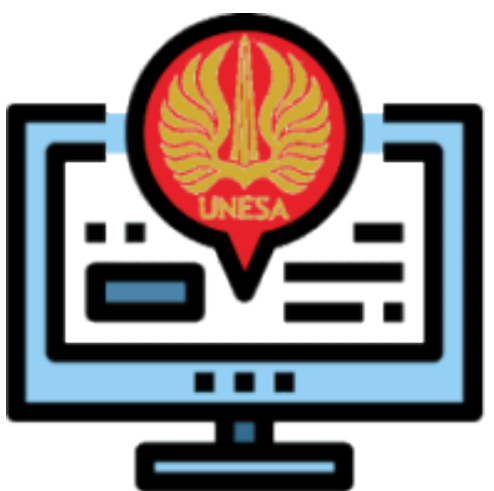

Figure 2. Product Icon After Installed on Android

\section{Production and merging of concepts}

Concepts that have been analyzed and collected supporting components are then combined to integrate them into an interactive learning media. The software used for merging and compiling scenarios is Adobe Animate CC 2019. The product obtained has the extension ".fla" then carried out exporting is with the help of Adobe AIR 33.1 SDK with action script 3.0 so that the extension ".apk" is specific for the Android type operating system.
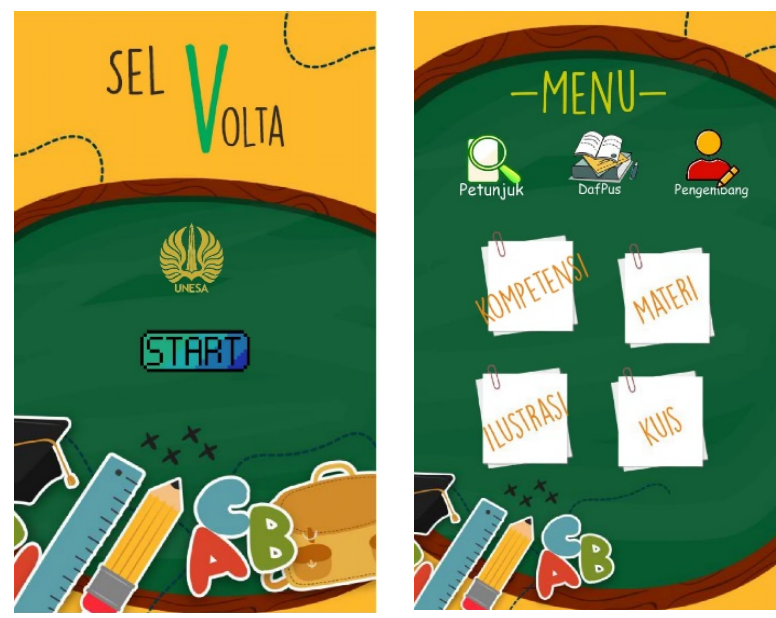

Figure 3. Initial View and Product Menu Created

\section{Development Phase and Limited-stage Trial}

The development phase is a follow-up to the phase design where the resulting product will be reviewed and validated by experts for further testing on a limited scale.

1. Validation

Product validation consists of content validity and constructs validity. Content validity is reviewed by several indicators of the suitability of the material presented in the product and curriculum used. 
Meanwhile, construct validity includes aspects in delivering material, graphics, and product language. The results of the study and validation by expert lecturers and chemistry teachers showed the following results:

Table 2. Media Validity Results

\begin{tabular}{llll}
\hline No & $\begin{array}{l}\text { Aspect } \\
\text { Assessment }\end{array}$ & Percentage & Category \\
\hline 1. & Content validity & & \\
& $\begin{array}{l}\text { Curriculum } \\
\text { Material }\end{array}$ & $90 \%$ & Very Valid \\
& presentation & $93 \%$ & Very Valid \\
& Evaluation & $97 \%$ & Very Valid \\
2. & Construct Validity & & \\
& Display Quality & $97 \%$ & Very Valid \\
& Software & $90 \%$ & Very Valid \\
& Engineering & & \\
& Implementation & $93 \%$ & Very Valid \\
& Language & $89 \%$ & Very Valid \\
& Interface & $93 \%$ & Very Valid \\
Compatibility & $90 \%$ & Very Valid \\
\hline
\end{tabular}

Table 2 shows that each aspect measured is in the very valid category range in each aspect. It can be said that the product produced in the form of learning media mobile learning (M-Learning) an Android-based, very valid overall aspect of $93 \%$.

\section{Limited-stage trial}

After the product has received validation from 2 expert lecturers and one chemistry teacher, a trial is carried out with the students' research subjects. Students are asked to measure their initial ability by doing ten pre-test questions for 20 minutes. Then the students are given an application in the form of instructional media products(M-Learning) to be installed in mobile phones for the learning process. After one day, students have again measured their academic ability by post-testing for 20 minutes. The students' pre-test and post-test results can be seen in table 3 .

Table 3. Pre-test and Post-test result

\begin{tabular}{llll}
\hline No. & Name & Pre-Test & Post-Test \\
\hline 1 & ADY & 40 & 20 \\
2 & ACI & 30 & 90 \\
3 & AF & 70 & 90 \\
4 & BAM & 50 & 60 \\
5 & DM & 40 & 40 \\
6 & DP & 30 & 40 \\
7 & DADA & 30 & 80 \\
8 & ETA & 20 & 100 \\
9 & FNA & 10 & 90 \\
10 & H & 20 & 90 \\
11 & IA & 60 & 90 \\
12 & IAAP & 10 & 90 \\
13 & KDC & 50 & 80 \\
14 & LNF & 40 & 90 \\
\hline
\end{tabular}

\begin{tabular}{llll}
\hline No. & Name & Pre-Test & Post-Test \\
\hline 15 & MRAP & 10 & 90 \\
16 & MRA & 20 & 100 \\
17 & MSK & 20 & 90 \\
18 & MDN & 60 & 100 \\
19 & NS & 50 & 30 \\
20 & RM & 60 & 100 \\
21 & RAF & 30 & 70 \\
22 & RAG & 60 & 90 \\
23 & SBNW & 40 & 80 \\
24 & SRS & 20 & 100 \\
25 & TT & 50 & 60 \\
26 & TK & 30 & 80 \\
\hline
\end{tabular}

In table 3, can students get an average score of 36.5 in the pre-test questions and 78.4 in the post-test questions. This data can be used as a parameter that the product developed is $41.9 \%$ effective if used to study the chemistry of voltaic cell sub materials in class XII MIPA 4 SMAN 1 Ngimbang, Lamongan.

\section{Conclusion}

The research was conducted to know the worthiness of learning media mobile learning (MLearning) is increasing students' learning effectiveness. The research results obtained a product validity of $93 \%$ with a very valid category. The product developed is considered able to increase the effectiveness of learners $41.9 \%$

\section{Acknowledgements}

The authors thank the supervisors and the entire academic community of the State University of Surabaya. Thank you to all respondents and those who have helped launch this article. Thanks to the authors of the articles and journals contained in this article.

\section{References}

Cahyani, A., Listiana, I. D., \& Larasati, S. P. D. (2020). Motivasi Belajar Siswa SMA pada Pembelajaran Daring di Masa Pandemi Covid-19. IQ (Ilmu AlQur'an): Jurnal Pendidikan Islam, 3(01), 123-140. https://doi.org/10.37542/iq.v3i01.57

Dewi, T. A. P., \& Sadjiarto, A. (2021). Pelaksanaan Pembelajaran Daring Pada Masa Pandemi Covid19. Jurnal Basicedu, 5(4), 1909-1917. https://doi.org/10.31004/basicedu.v5i4.1094

Hadi, K. (2019). Desain dan Uji Coba Praktikum Green Chemistry dengan Memanfaatkan Logam Bekas pada Sel Volta. Konfigurasi: Jurnal Pendidikan Kimia dan Terapan. 3(2). http://dx.doi.org/10.24014/konfigurasi.v3i2.7607 Hidayat, D. R., Rohaya, A., Nadine, F., \& Ramadhan, H. (2020). Kemandirian Belajar Peserta Didik Dalam 
Pembelajaran Daring Pada Masa Pandemi Covid 19. Perspektif Ilmu Pendidikan, 34(2), 147-154. https://doi.org/10.21009/pip.342.9

Kartini, K. S., \& Putra, I. N. T. A. (2020). Respon Siswa Terhadap Pengembangan Media Pembelajaran Interaktif Berbasis Android. Jurnal Pendidikan Kimia Indonesia, 4(1), 12. https://doi.org/10.23887/jpk.v4i1.24981

Lubis, I, R., \& Ikhsan, J. (2021). Pengembangan Media Pembelajaran Kimia Berbasis Android Pada Materi Termokimia Kelas XI SMA. Jurnal Inovasi Pendidikan IPA, 1(2), 191-201. https://doi.org/10.21831/jipi.v1i2.7504

Oktarina, S., \& Sahono, B. (2020). Pengembangan Media Pembelajaran Berbasis Android untuk Meningkatkan Prestasi Belajar Siswa. 1(1), 71-75.

Putri, Y. D., Elvia, R., \& Amir, H. (2021). Pengembangan Media Pembelajaran Kimia Berbasis Android Untuk Meningkatkan Motivasi Belajar Peserta Didik. ALOTROP: Jurnal Ilmu Pendidikan Kimia. 5(2), 168-174. https://doi.org/10.33369/atp.v5i2.17138

Putria, H., Maula, L. H., \& Uswatun, D. A. (2020). Analisis Proses Pembelajaran dalam Jaringan (DARING) Masa Pandemi Covid- 19 Pada Guru Sekolah Dasar. Jurnal Basicedu, 4(4), 861-870. https://doi.org/10.31004/basicedu.v4i4.460

Ramdani, A., Jufri, A. W., \& Jamaluddin, J. (2020). Pengembangan Media Pembelajaran Berbasis Android pada Masa Pandemi Covid-19 untuk Meningkatkan Literasi Sains Peserta Didik. Jurnal Kependidikan: Jurnal Hasil Penelitian Dan Kajian Kepustakaan Di Bidang Pendidikan, Pengajaran Dan Pembelajaran, 6(3), 433. https:// doi.org/10.33394/jk.v6i3.2924

Setiawan, N. C. E., Dasna, I. wayan, \& Muchson, M. (2020). Pengembangan Digital Flipbook untuk Menfasilitasi Kebutuhan Belajar Multiple Representation pada Materi Sel Volta. Hydrogen: Jurnal Kependidikan Kimia, 8(2), 107. https:// doi.org/10.33394/hjkk.v8i2.3194

Siahaan, K.W.A., Manurung, H.M., \& Siahaan, M.M. (2021). Android-Based Learning Media Development Strategies During Pandemic Times To Improve Student Science Literature. International Journal of Education and Humanities, 1(1), 34-42. Diambil dari http://www.ijeh.com/index.php/ijeh/article/view/4

Sophia, A. (2019). Android-Based Interactive Learning Multimedia Validity in Genetic Substance and Synthesis Protein for Students of Medical Laboratory Technology (TLM). International Journal of Progressive Sciences and Technologies. 6(1). 123-126.

http://dx.doi.org/10.52155/ijpsat.v16.1.1219
Surat Edaran Mendikbud No 4. (2020). Surat Edaran Mendikbud No 4 Tahun 2020 Tentang Pelaksanaan Kebijakan Pendidikan Dalam Masa Darurat Penyebaran Corona Virus Disease (COVID- 19). 4, 14.

Syarifuddin, M. K., \& Dwiningsih, K. (2020). the Validity Multimedia Interactive Bases Android on Ionic Bond Material. JCER (Journal of Chemistry Education Research), 4(2), 63. https://doi.org/10.26740/jcer.v4n2.p63-70 